\title{
CAN SHARED PRACTICES BUILD A NEW CITY?
}

\author{
Cristina Bianchettia ${ }^{a}$ Angelo Sampieri ${ }^{b}$ \\ DIST - Interuniversity Department of Urban and Regional Studies and Planning, Politecnico di Torino, \\ C.so Mattioli 39, 10125 Turin - Italy \\ E-mail: acristina.bianchetti@polito.it (correspondingauthor); bangelo.sampieri@polito.it
}

Received 18 November 2013; accepted 14 February 2014

\begin{abstract}
Contemporary living is increasingly marked by different kinds of associationisms, collective but not necessarily longlasting actions, and either little or very determined communalities. This article will discuss forms of living that reject individualism and shy away from communities. Indistinct forms, based on living "side by side, walking in step" which Bauman (2002) described as "a desperate need for networking"; and Sennett (2008) said was "the force of wandering emotions shifting erratically from one target to another". Characterised by values such as ecology, frugality, reciprocity and solidarity. We believe that the key issue is to understand whether these forms are capable, as they say they are, of metaphorically rebuilding the city. In other words, can they implement a different concept of urbanity and public space by adopting the role played in late capitalist cities by conflict, rationality, functionalism, and the market. To tackle the problem we must first understand how they affect three different issues: the first involves changes in the values assigned to living; the second, the new logic of spatial organisation; the third, the revision of the notion of public and its political consequences. In order to provide greater clarity, we will deal with these three issues by briefly referring to European case studies carried out by a group of town-planners and sociologists.
\end{abstract}

Keywords: shared living, associationism, urbanity, living values, spatial organization, public realm.

Reference to this paper should be made as follows: Bianchetti, C.; Sampieri, A. 2014. Can shared practices build a new city?, Journal of Architecture and Urbanism 38(1): 73-79.

\section{Introduction ${ }^{1}$}

Plan-les-Ouates is a residential suburb in the wealthy city of Geneva. A dozen families belonging to the Mill'O cooperative decided to design a communal house based on ecological principles and a life in common: large communal areas, a large playground area for the children, kitchen gardens, open spaces, and lots of spontaneous vegetation to underline the difference with their neighbours' well-kept hedges and flower pots (Bianchetti 2012). This is the ideal type of cohousing, with rigid rules, maniacal task sharing, and strict access rites. A situation where people work hard, argue endlessly about everything, say they behave

\footnotetext{
1 The whole paper was jointly written by the two authors, except for the second and fourth paragraph, written by Cristina Bianchetti, and the first and third paragraph written by Angelo Sampieri.
}

morally, and lead a healthy life based on a behaviour involving saving, recycling, salvaging, and using the least amount of resources. The inhabitants of Mill'O proudly declare that rich and poor people live in the house which stands smack in the middle of a residential suburb, but ignores it. It uses urban services, but has an almost secessionist, anti-urban attitude.

Something similar to 53 Strelitzer Strasse in Berlin where a village is hidden behind a six story street front building (Sampieri 2012). Here secession cuts through the heart of the city next to Mauerpark, along Bernauer Strasse: symbolically the most powerful place in this European city which first celebrated and then destroyed the wall. Sixteen terraced houses create a small inner city village, a hidden elitist niche carved by a handful of families and protected from cars, noises and urban life. With big communal spaces and reciprocal intrusive views. 
In the Brabante district a community of squatters evicted from the city have colonised the rough, former industrial area of the inner suburbs. Supported by close-knit associative networks, they relocate the principles of solidarity, conviviality, creativity and self-management to these abandoned areas. While these principles had inspired the urban warfare and squatting of the seventies and eighties (Pattaroni 2012), the squatters now exploit principles such as self-subsistence, degrowth, and ecology: an intense affective investment. Although these phenomena are limited, they claim they are innovative, exemplary and radical. What Paolo Grossi (1977) would call (paraphrasing Carlo Cattaneo) "a different kind of ownership".

In Helmond young families with an urban past have decided to go back to country living (Conticini 2012). New farmers focusing on biodynamic agriculture, permaculture, stock farming, and the promotion of workshops and events (almost pagan rites, such as the Celebration of Spring, Silence, and the Sun). They create associations promoting the theories of degrowth and subsistence economies; they farm the land, administer entrepreneurial activities, and work on twitter. Communes which are vaguely hippy and in some way recall the libertarian wanderings of Americans in the fifties (Jackson 1984), or a certain Anglo-Saxon anarchism of the sixties (Ward 1982). They live outside the city and adopt pioneer strategies. Shouting loudly that they have abandoned the city and distanced themselves from modern living.

Colonisation involves not only abandoned land, but also fringe agricultural territories. It cuts into the compact and resistant fabrics of the nineteenth-century city. In Lyon, many jardins partagés are dotted around the old fabric of a city which in the nineties made large, monumental public spaces the focus of its policies (Giannotti 2012): examples include the squares of the Presqu' île redeveloped by the best French architects and landscape architects, and the banks of the Rhône and Saône redesigned based on a logic of public reappropriation of river views, the so-called Confluence project. Small introvert and fragmented spaces reflecting a different way of living with others and sharing urban space. The compact nineteenth-century city blocks in Brussels are colonised by artisan, artistic, and cultural associations which invade courtyards, ground floors, and empty warehouses. In most cases temporarily, and supported by public policies. These collective activities produce intense regeneration (Inti 2013).

Finally, Milan. Olinda is an excellent example: a not-for-profit cooperative located in the grounds of the former Paolo Pini psychiatric hospital in the northern city suburbs (Bricocoli 2012). Olinda's goal is to gener- ate urbanity where there was none. A summer festival, an open theatre in the former refectory of the lunatic asylum, a slow food restaurant in the former morgue, a hostel and communal kitchen gardens. All this is more than just an imaginative reuse of space; many people are attracted by these new suburban centralities which compete against the whole city.

\section{Living entre nous}

Cases such as these are frequent in the countryside and cities of Europe. However, in most cases they are limited, localised, and more often than not temporary. They might not seem much: the frivolous invention of a few individuals, an excessive dissipation of energy. Undoubtedly they are relatively insignificant compared to the increasingly difficult housing situation more and more people have to face. Nevertheless they do attract a lot of attention, and are constantly being debated. The current focus is on making a little go a long way, on doing things for other people, on avoiding the market and institutions. People reiterate the importance of forms of living based on certain behaviour codes of frugality, recycling, hyperactivity (to demonstrate abundant human means and resources instead of flaunting wealth and abundance), a new architectural and emergency culture capable of inspiring a design which is primarily an exhortation - Design Like You Give A Damn (Architecture for Humanity 2006 2012), and trust in an outcome that moves beyond the boundaries of specific situations - Small scale, big change (Lepik 2010) - so that we remember that something very important is at stake, even if we have to still focus on the little things.

We should immediately point out that celebration simplifies matters: sharing is neither intrinsically good, nor is it powerful enough to solve basic problems, for example the breakdown of "organic" solidarity ties which Durkheim believes is a characteristic of modern society. Sharing coexists with contrast and conflict, and sometimes helps to create them. It can turn into the protection of the included, secessionist behaviour and appropriation of rights. It opens a Pandora's box of questions at a time when the robust networks of social protection created during the second half of the twentieth century (Castel 2003) have turned to dust and the search for something that frees us from solitude ${ }^{2}$ becomes increasingly important.

We intend to put forward the following hypothesis: that although these sharing episodes might seem in-

2 The expression was coined by Jaques Donzelot, and refers to the urban movements of the eighties (Donzelot 2009). 
significant we should study them carefully because they reveal significant changes in the values assigned to living in contemporary society. Suspended midway between the search for individual solitude and collective pathos, they reveal another perspective: the end of the protection of the individual and his liberties or the protection and establishment of communities which marked twentieth-century architecture and town planning, and the emergence of a desire to live entre nous, with a small circle of friends and neighbours where the individual opens a window on a world which is his, but not only his. A world which creates and reflects common beliefs, actions and experiences.

Living entre nous means ten, fifteen, twenty families living together and working hard together. Almost everything has to be done. They work hard to construct the building, or maintain the communal spaces where daily activities take place. Everything has to be negotiated and actions and solutions have to be constantly redefined. Extensions, number of members, consumption, and emissions. Assignment of tasks, roles, and functions. The protagonists are mostly young people, families with children, unconventional families, individuals with a solid cultural background allowing them to imagine and undertake unusual projects and establish elective and selective relationships marked by a certain degree of freedom.

Entre nous concentrates meticulously on what is within its boundaries, and less on what is beyond them. Convinced that there is a lot within those boundaries, even for those on the outside ${ }^{3}$. Surplus energy and services for the city. Actually, more careful scrutiny shows this surplus to be nothing to write home about: a street festival, a small market selling fruit and vegetables or second hand objects, an art exhibit, a few performances. What's more important is the sparkle, zing, and repercussions of the actions performed there; while these actions project a very dynamic image they do not create centrality but small, protected worlds which are hospitable at the same time. The principle of conviviality on which they are based contradicts their open approach, because the latter includes rules as well as behavioural and aesthetic codes. The kitchen garden, the woodpile, the greenhouse, small manmade sheds in which to store tools or bicycles. Things which can be done at home. Indicating a quiet, not very eclectic

\footnotetext{
This is one of the many elements characterising the difference between current considerations and those formulated at the end of the nineties when the focus was mainly on autistic forms of living, which François Ascher and Francis Godard called, very successfully, "convex" groups, a term used to describe the fact that social relations occurred only within the groups. For a long time, gated communities were a recurrent example (Ascher, Godard 1999).
}

domesticity, rewritten within the boundaries of a world which at times is primitive, simple, and elementary, like the architectures which shape it.

Exactly what does entre nous mean? What is shared in shared territories? Sharing involves projects, values, alliances, concerns, fears, and memories. And also antagonists: first and foremost a homologating and functional market logic considered to be not only extremely unjust, but also responsible for exacerbating social inequalities and excluding large swathes of the population. Second, territorial planning, considered technocratic, constricting, and incapable of recognising genuine territorial resources or taking into account the voice of people who live there; planning dictated by a rationality considered as a dogma. Third, institutions (even if many of these forms are actually backed by public actions or capitals, and even the ground on which they stand is often public). Institutions are accused of implementing hypertrophic, abstract, bureaucratic, and citizen-unfriendly rules and regulations. Juxtaposed against all this, sharing glorifies immediacy, personal relations, proximity, and do-it-yourself. This juxtaposition (between rules and immediacy) conceals the desire to discard many of the constructs of modernity, especially the mediation typical of modern institutions.

Sharing involves projects, values, memories, antagonists, and the assertion of rights. All this is evident in the continuous demand for rights: the right to live in small groups based on empathy rather than market rules; the right to use or produce certain services; the right to physically look after communal spaces in person; the right to slow mobility, to local agriculture, to artisanal work in small groups; the right to radical ecologism, to the notion of village deeply embedded in a city with which to entertain close relations and enjoy adjacent spaces. This is an incomplete list, even if it's obvious that the right of ownership - the protagonist of eighteenth-century documents establishing the modern meaning of a legal subject - has been relegated to the back burner.

A demand for rights which has little or nothing to do with general requirements and more to do with specific, local situations involving one's own group. A question springs to mind: what rights? When do the interests that unite these small groups turn into rights, civic duties, or values in whose name individuals are encouraged to abandon individualistic or community niches? What do they have in common with the often repeated concept of droit à la ville (Lefebvre 1968) with which they share its qualitative traits, but not its general overall dimension? Almost as if the primacy of the value of use is considered something that splits into plural, diversified and sometimes contradictory uses. 
As a result, the droit à la ville explodes in a continuous demand for uses, privileges, and immunity ${ }^{4}$ which, to all intents and purposes, modifies the notion of proximity, neighbourhood, and citizenship. However, these protected, tolerated, and regulated demands focus on specific situations and make little reference to a general situation.

\section{A different spatial order}

Shared spaces alter the way we look at a city. For two interrelated reasons: because they do not follow a traditional spatial order, and because the sense of belonging demanded by living entre nous no longer pertains to the modern city. How do these phenomena occur in space? And how can we build, in space, "strategies of distinction" (Bourdieu 1979) which refer to the change in values mentioned earlier?

First of all, sharing is not based on traditional spatial logic. For example, it is not based on a hierarchical and oppositive logic which distinguishes between the centre and the suburbs, between the compact city and sprawl, between exclusive areas and degraded areas. Neither is it based on a radial or ring-shaped logic emphasising continuity and directionality, like large twentieth-century residential complexes which create a satellite-shaped, radiocentric expansion, an expansion which is multifaceted compared to infrastructures and urban layout. Nor is it based on an isotropic logic similar to the one characterising the 'fine dust' of single family houses in the diffuse city. And finally, nor is it based on an elitist, exclusive, club-style logic of enclaves and gated communities: residential archipelagos where it is important to appropriate places of value and reiterate the acquired right to be there, simply because one lives there. A proliferation of exceptions replaces pyramidal hierarchy, linearity, or isotropy.

Plan-les-Ouates, Eindhoven, Milan and Berlin: sharing occurs in the rich suburbs of rich cities, in hard, compromised, and abandoned places, in agricultural land which has lost its value or the possibility to produce it, in consolidated suburbs, in the symbolically most powerful places in European cities, and in compact nineteenth-century urban fabrics. Quite simply, sharing goes where it can. Or rather, where certain conditions exist: poorly protected spaces; hidden, residual spaces: spaces where their use has been suspended or interrupted; places temporarily 'in waiting'; enclaves of public properties. Appadurai would say: it is there

\footnotetext{
4 "A bundle of rights" is the formula developed by W. N. Hohfeld (1919). The image of a bundle of rights is present in many law books. For books focusing more on town planning see: P. Marcuse (1994).
}

that sharing produces locality. It inscribes relations in space and rebuilds economic values. It introduces new configurations and establishes rules which organise a different way of living marked by spontaneous vegetation or the clutter of domestic furnishings exposed in communal space.

Sharing measures itself against urban space which it considers as being totally accessible. Without having to conjure up a specific and well-defined condition. Very different to the spontaneous spatial order celebrated by Colin Ward in the seventies, and yet able to maintain a certain degree of eventuality. These are single phenomenon which emerge like accidental blips in the weave of the city, the European city, very attentive in many other ways to how diversifying its functions and preserving its spatial, cultural, political, and welfare infrastructures.

It is important to capture the very small and reiterated discrepancies created by sharing in urban space. Small variations of intensity. Deviations which make some places more important than others, because it is there that a "sense of social immediacy"5 and a change in economic and symbolic values are inscribed. These tiny tremors slowly shatter linear tales: the sad tale of decline, and the comforting tale of regeneration. It changes the interpretation of the former industrial area of Tilburg, but also the meaning of the revitalisation of inner city districts in Brussels.

Design culture and public debates still refer to these shattered tales and damaged images of cities: the multipolar city, the archipelago city, the scattered city, the organicist city in which everything is held together, or its opposite, the balkanised city in which everything is separate. Images which, unable to intercept the tiny, persistent and, in their own way, strong energies of sharing, now require a change of perspective: abandonment of general views and a close focus on sudden changes, fractures, and limits; on the sporadic succession of spaces filled with relationships and interactions, and on looser and more rarefied spaces; on the particularism of goals, roles, and identities which create different and divergent worlds in the same city.

\section{A minor public}

In the minds of town planners and sociologists urbanity means creating a close-knit web of ties, exchanges, solidarity, and conflicts. On the contrary, a city which

\footnotetext{
5 Appadurai considers this one of the traits of the "production of locality"; he distinguishes between this and the more stable state of neighbourhood (Appadurai 1996: 178).
} 
"comes undone" 6 is a city in which distance, separation, and fractures reign supreme. This logic severely undermines what we normally consider are the key traits of a city: miscellany, integration, and pluralism (Donzelot 2008). Our aim is to find out whether sharing can act against these distancing processes, in other words whether it is able to generate urbanity.

Our case studies did not deliver a clear answer. In some cases, the answer was yes, for example Olinda in Milan: its key trait was their determination to build and "create a city where there was none" (Bonomi 2009), by exploiting any kind of collective work to reinvent services, create new public areas, and break the barrier between the world of welfare and production. In other cases, the answer was no, for example Mill'O in Geneva: here the main trait was secession, the tendency to implement in-house solidarity and avoid being part of mainstream welfare and its spatial forms. In Olinda, a lot depended on the presence of a group of very different individuals (fairly impossible to envisage beforehand), while in Mill'O ties were established between similar individuals who chose each other. In both cases, the "entre nous" logic was not characterised by being able to 'do or undo' the city, but by the ability to rebuild selective and elective relationships within a small circle of individuals.

This discussion might not seem very different to the ones held in similar milieus in the nineties? But in fact the radical transformations of the last ten years have exasperated trends ${ }^{8}$, made them more multifaceted, and clarified several intrinsic aspects. The first is undoubtedly the rejection of the concepts behind the modern city, because sharing clearly does not base its sense of belonging on the modern functional city with its defined orders, a city capable of incorporating differences in a coherent civic space and reflecting conflicts, values, and rights in a transparent manner. The city conjured up by sharing is not the result of multiple interactions between actors operating within unitary, conflicting or concordant frameworks. Making actions weaker and multiplying frameworks are juxtaposed against that idea. In other words, the many specific actions promoted by associations, cooperatives, and more or less stable, cohesive and protected groups are not always reflected in participative and democratic demands; not always

${ }^{6}$ Quand la ville se défait, is not just the title of a famous article in the magazine Esprit (no. 258, November 1999) written by J. Donzelot and O. Mongin. Donzelot often refers to the article when he discusses the relationship between the organisation of space and the "desolidarisation de la societé" (Donzelot 2008).

7 Debate in the magazine Esprit, 1999, 258: 83-189.

8 At the time only gated community existed, Donzelot (2008), Quand la ville se défait, cit. are they turned into the counter-democracy touted by Rosanvallon (2006): they remain "by themselves" rather than become part of institutions ${ }^{9}$, society, or the city. Likewise, the spaces within which these actions occur, also remain enclosed.

Shared spaces tell us that the modern city is a thing of the past. Even the most powerful mythography, the one between polis and democracy, seems to have lost its grip, and so has the notion of public which has always been its mainstay; the fact it is going through a crisis cannot be attributed to shared living. However, since the latter replaces a polished and powerful concept, it can help explain the ambiguous combinations between common space and personal space. Sharing does not reject the notion of public, it chips away at it. In the phenomena outlined earlier there's nothing similar to the "almost religious" way in which people come together to share common expectations: the public is not a solid mass capable of representing a political institution, it is a seething mass of links generated by the decision to do something together ${ }^{10}$.

It is foreign to the logic of capitalisation. Foreign to the reciprocal visibility which makes us all identical and yet lets us retain our own individuality, in the sense intended by Arendt (1958). It refers to temporarily having something in common, to living in small groups to share something, and to the decision to identify with this approach. Arendt's visibility is replaced by the half shadow of adjacent relations. It is a "minor public" with a strong coefficient of territorialisation, a circumscribed collective value. Minor in the sense intended by Deleuze: severed from its stable and long-lasting nature, but nevertheless generative and open ${ }^{11}$. More than anything else, the revision of this concept emphasises its irreparable distance from the modern city.

The theory that it's useful to observe forms of sharing because they reveal changes in the values of contemporary living triggers another effect: it forces us to imagine other ways in which private life and forms of political expression are linked. But is this a legitimate link? Can the cautious, vague, and at times opportunist

9 The discontinuities present in institutions during this period of "great transformation" (in the sense intended by Robert Castel rather Karl Polanyi) are the topics researched by Ota de Leonardis who summarises some of his thinking in "Sulle tracce delle innovazioni istituzionali”, in de Leonardis (2010).

${ }^{10}$ Recalling Dewey and the pluralisation of the notion of public (Dewey 1954).

${ }^{11}$ Minority is used in the sense intended by Deleuze when he describes Carmelo Bene's theatre. It is not reduction, but an opening. Deleuze writes: "Let's imagine that he [Bene] cuts off one of the elements of the original work: he takes something away [...] He proceeds using subtraction and amputation, not addition. The work will then [...] swing around, turn on itself, and rest on something else. By eliminating Romeo, we can watch a staggering development [...]" (Deleuze 2002: 85). 
ties of shared living be interpreted as an attempt to revise the categories of citizenship? As a way to strive towards a democratic space, albeit of a different nature compared to Habermas' theory of the public sphere?

In today's world many people want to reconcile a focus on the individual with universal aspirations for justice and social equality including, on the one hand, the so-called theorists of radical democracy (Laclau, Mouffe 1985; Mouffe 2007; Butler et al. 2010), and on the other, those who want to recover the pragmatic idealism of the progressive era (Amin, Thrift 2002). A sincere aspiration which often ends in overemphasis on the prismatic pulverisation of the social and its virtues. It tends to acknowledge, more often and more cautiously, that the multiplication of horizontal ties gives rise to revisable and sporadic forms of solidarity. Apart from the two extremes of opportunist cynicism emphasising the pulverisation and religious adherence to solidarity and trust, it's still doubtful whether the political dimension is relevant to shared living.

And yet, politics must still deal with it. Locally. By drafting partial, regulatory, medium-term agreements which can be revised if the need arises. By imagining different forms of lightweight public action aimed at catalysing energy. By enhancing and directing associations towards a dialectics of mediation without falling into the age-old trap that attributes primacy to heretical and heterodox behaviours. By imagining projects which do not end in the creation of new mythographies and do not generically invoke capabilities and ideal forms of the transmission of skills, but know how to tackle the diffidence sharing has towards design and political knowledge which is never considered as a value in itself. In other words, by trying to harness the critical power of the notion of partage, fully aware that it has to measure up against a change in equivocal and at times paradoxical traits: something very different to the holistic concept of politics, the city, and society.

Like the modern city, the republican model of society fashioned by the state and by citizens educatable by politics, is now definitely a thing of the past.

\section{The question posed by Roland Barthes}

On January 12, 1977, Roland Barthes delivered the first of fourteen lessons he gave as part of the Course on Literary Semiology at the College de France. The course entitled "Comment vivre ensemble" had been organised less than a year earlier by Michel Foucault (Barthes 2002). To recognise the importance of the issue raised by Barthes - what exists between solitude and community? - we are not required to adhere to the hard, ruthlessly systematic and guiding nature of semiology in the seventies, the science that fascinated so many people even outside the world of literati. How far away should we be from others to free ourselves from a state of exile, without falling into secular or religious isolation? Barthes' question is still useful to understand important features of the contemporary city. Because it induces us to focus on tangible actions firmly rooted in the present. The tangible dimension of actions are fundamental in the cases we cited earlier.

Pragmatic actions aimed at rewriting an objective of common actions, and avoiding utopias not immediately implementable. In the best pragmatic tradition. It's not a question of recreating sociality from thin air, but of making contemporary projects, values, memories (and concerns) visible and feasible. One could argue that the colonisation of the countryside with small farms, or the community liberalism of the fifties, or the displacement of the principles and memories of the urban battles of the seventies, are all nostalgic operations. And ultimately conservative.

This is undoubtedly true. The counterargument is that nostalgia is less important than the attempt to reveal contemporary tensions, values, and concerns. Values of frugality which, taken to the extreme, become an eulogy of poverty. Of ecology and simplified degrowth. Of solidarity resulting in the tender humanism criticised by Foucault. We can like or dislike these values. However, it is in this horizon of vehemently demanded claims, uses, and prerogatives, that the twentieth-century city becomes a 'whole' packed with distant, simple and straightforward ideas and moral imperatives. While the configuration of a new city still remains vague and uncertain.

\section{References}

Amin, A.; Thrift, N. 2002. Cities: reimagining the urban. Cambridge: Polity Press.

Appadurai, A. 1996. Modernity at large. Minneapolis: University of Minnesota Press.

Architecture for Humanity. 2006. Design like you give a damn. Architectural responses to humanitarian crises. New York: Metropolis.

Architecture for Humanity. 2012. Design like you give a damn 2. Building change from the ground up. New York: Abrams.

Arendt, H. 1958. The human condition. Chicago: University of Chicago Press.

Ascher, F.; Godard, F. 1999. Vers une troisième solidarité, Esprit 258: 168-189.

Barthes, R. 2002. Comment vivre ensemble. Cours et séminaries au College de France (1976-1977). Texte établi, annoté et présenté par Claude Costa. Paris: Seuil IMEC.

Bauman, Z. 2002. Individually, together, in U. Beck, E. BeckGernsheim (Eds.). Individualization: institutionalized individualism and its social and political consequences. London: Sage. 
Bianchetti, C. 2012. Mill'O, Plan-les-Ouates, Geneva [online], [cited 16 September 2012]. Available from Internet: http:// territoridellacondivisione.wordpress.com/2012/09/16/ millo-plan-les-ouates

Bonomi, A. 2009. La città fragile, Communitas 37/38: 7-23.

Bourdieu, P. 1979. La distinction. Critique sociale du jugement. Paris: Minuit.

Bricocoli, M. Olinda, Milan. Producing urbanity through a social entreprise [online], [cited 4 November 2012]. Available from Internet: http://territoridellacondivisione.wordpress. com/2012/11/04/olinda-producing-urbanity-through-asocial-entreprise

Butler, J.; Laclau, E.; Žižek, S. 2010. Dialoghi sulla sinistra. Bari: Laterza.

Castel, R. 2003. L'Insécurité sociale: qu'est-ce qu'être protégé?. Paris: Éd. du Seuil.

Conticini, A. 2012. B5. Helmond/Willemsvaart Kanaal [online], [cited 29 June 2012]. Available from Internet: http:// territoridellacondivisione.wordpress.com/2012/06/29/ helmond-willemsvaart-kanal

de Leonardis, O. 2010. Sulle tracce delle innovazioni istituzionali, RA - Rivista elettronica dell'AIS 1: 69-78.

Deleuze, G. 2002. Un manifesto di meno, in C. Bene, G. Deleuze, Sovrapposizioni. Macerata: Quodlibet, Macerata.

Dewey, J. 1954. The public and its problems. Athens: Swallow Press-Ohio University Press.

Donzelot, J. 2008. Quand la ville se défait. Quelle politique face à la crise des banlieues?. Points, coll, Points Essais.

Donzelot, J. 2009 La ville à trois vitesse. Paris: Éditions de la Villette.

Giannotti, E. 2012. Lyon. Guillottière [online], [cited 15 April 2012]. Available from Internet: http://territoridellacondivisione. wordpress.com/2012/04/15/lione-guillotiere-14

Grossi, P. 1977. Un altro modo di possedere. L'emersione di forme alternative di proprietà alla coscienza giuridica postunitaria . Milan: Giuffrè.

Hohfeld, W. N. 1919. Fundamental legal conceptions as applied in legal reasoning and other legal essays, 3rd edition, New Haven: Yale University Press.

Inti, I. Micro-Marché, dispositivi per fare città a Bruxelles, [online], [cited 20 January 2013]. Available from Internet: http://territoridellacondivisione.wordpress.com/2013/01/20/ micro-marche-dispositivi-per-fare-citta-a-bruxelles/

Jackson, J. B. 1984. Discovering the vernacular Landscape. New Haven: Yale University Press.

Lefebvre, H. 1968. Le droit à la ville. Paris: Anthropos.

Laclau, E.; Mouffe, C. 1985. Hegemony and socialist strategy. London: Verso.

Lepik, A. (Ed.). 2010. Small scale, big change. New architecture of social engagement. New York: The Museum of Modern Art.

Marcuse, P. 1994. Property rights, tenure and ownership: towards clarity in concept, in B. Donermark, I. Elander (Eds.). Social rented housing in Europe: policy, tenure and design. Delft: Delft Unversity Press, 21-39.

Mouffe, C. 2007. Sul politico. Democrazia e rappresentazione dei conflitti. Milan: Bruno Mondadori.

Pattaroni, L. 2012. Le friches du possible. Petite plongée dans l'histoire et le quotidien des squats genevois, in J. Gregorio (Ed.). Squats. Genève 2002-2012. Genève: Labor et fides.
Rosanvallon, P. 2006. La contre-démocratie. La politique à l'âge de la defiance. Paris: Seuil.

Sampieri, A. 2012. 53 Strelitzer Strasse. Berlin [online], [22 September 2012]. Available from Internet: http:// territoridellacondivisione.wordpress.com/2012/09/22/ strelitzer-strasse-53-berlin

Sennett, R. 2008. The craftsman. London: Allen Lane/Penguin Press.

Ward, C. 1982. Anarchy in action. London: Freedom Press.

\section{CRISTINA BIANCHETTI}

Full Professor in Urban Planning, DIST - Interuniversity Department of Urban and Regional Studies and Planning, Politecnico di Torino, C.so Mattioli 39, 10125 Turin, Italy.

E-mail:cristina.bianchetti@polito.it

Research Interests: urban design, urban studies, community development, housing,

\section{ANGELO SAMPIERI}

Assistant Professor in Urban Planning, DIST - Interuniversity Department of Urban and Regional Studies and Planning, Politecnico di Torino, C.so Mattioli 39, 10125 Turin, Italy.

E-mail: angelo.sampieri@polito.it

Research Interests: urban design, urban studies, community development, housing. 